\title{
FACEBOOK GROUP AND STUDENT ENGAGEMENT
}

\author{
Santirianingrum Soebandhi ${ }^{1, \mathrm{a}}$, Natalia Damastuti ${ }^{2, \mathrm{~b}}$, Novi Nurul Quina ${ }^{3, \mathrm{c}}$ \\ ${ }^{1,3}$ Faculty of Economics and Business, Narotama University Surabaya, Indonesia \\ ${ }^{2}$ Faculty of Computer Science, Narotama University Surabaya, Indonesia \\ asantirianingrum@ narotama.ac.id, ${ }^{b}$ natalia.damastuti@ narotama.ac.id, ${ }^{\mathrm{c}}$ novi.nurul@ narotama.ac.id
}

\begin{abstract}
This study aimed to investigate the impact of the use of Facebook groups on student learning process. This group is intended as a communication and discussion tool and means for collecting assignment, therefore all members of this group can access the course related materials. Online questionnaire using Likert scale and open-ended section is used at the end of the course to know the response of students to the use of this group. We obtained 57 responses from 77 enrolled students from Management Information System subject. The results showed that the FB Group enhanced engagement both on the course and lecturer, and can be used as educational tools in higher education.
\end{abstract}

Keywords: Facebook group, student engagement, educational tools, higher education, online questioner

\section{Introduction}

The intensive use of FB among students can be utilized as educational tool in higher education [1]. Currently, Indonesia is the fourth largest Facebook user in the world [2] and ranked third of Facebook application on mobile phone [3]. This phenomenon can be used by the lecturer to function Facebook as a media of students learning. The features in FB group that allows students and lecturer to discuss, sharing course materials, upload and download files are useful during the learning process. The notification which appears each time group member post in the group makes it easy to always have the latest information. With this FB group, the interaction both between lecturer, students and between the students themselves can be implemented.

\section{Literature Review}

Facebook in Education. The use of Facebook in education system has gained many opinions. Previous studies argued that social network sites (SSNs) like Facebook should not be used for the learning process because it can interfere and impede student achievement [4] though sometimes Facebook is used informally for learning purposes, but it should be used for social reasons and not for formal teaching purposes [5]. Meanwhile, studies that agree on the use of Facebook argued that 
Facebook can increase student motivation for learning, engagement, and collaboration among students $[6,7]$.

Student Engagement. Student engagement indicates readiness, needs, and wants of the students to actively participate in daily school activities [8]. Student engagement also represents the time and energy devoted by students to interact with others through activities related to the educational practices and the work done by institution to implement effective practices in education [9]. To increase student engagement in learning, [10] proposed as follows: (1) interaction (relationship and interaction of both personal and virtual [11] with the teacher, other students, and the community [12], (2) exploration (the opportunity to explore and find a solution), (3) relevance (relevant to the issue that is going on, not theoretical), (4) multimedia and technology (access and interact globally), (5) instruction (constructive instruction that allows students to feel capable and comfortable to have discussion with the lecturer as part of the learning process [11]), and (6) authentic assessment (cocreation with the lecturer to guide the assessment of student learning [13]).

\section{Methodology}

Respondents. Target respondents were Accounting major students enrolled in Management Information Systems course, Narotama University, academic year 2015-2016. This class consists of 77 students. From 77 targets of respondents, we obtained 57 responses with a composition of $87.7 \%$ female and $12.3 \%$ male with a mean age of 22 years and with an age range from 19 to 25 years.

Data Collection and Analysis. Online questionnaires using a combination of question types, including single answer (yes or no), checklists, frequency-scaled questions, Likert scale and openended question were given at the end of the course. Questionnaires were used to obtain demographic information on respondents, interaction and participation, opinions on the use of FB group as a learning tool and its impact on engagement. As for opinion statements, data is collected into tables and graphs for interpretation.

Facebook Group. "Closed" Facebook Group created at the beginning of the lecture (in closed group only member who can see the posts) and for students who do not have an account will be assisted to create one. Of all respondents were only three students who do not have a FB account. Activities in this group include putting up announcements, sharing course materials, submitting assignments, and discussion.

\section{Result}

Frequency of Accessing Facebook. By using the frequency scale (every day, several days, several weeks, and never), respondents were asked how often they access their FB account in one month. 
Twenty five respondents (43.9\%) said they quite often access the FB, although not every day, sixteen respondents (28.1\%) access the FB every day, nine (15.8\%) access the FB a few weeks, and the rest $(12.3 \%)$ never access FB.

Use of FB group. The next question related to how respondents use of MIS's FB group. Students were asked if they participated (post and read) in the group. The results showed that all members are participating in this group although rarely (see Table 1). In terms of doing a post on the group (comments, assignment, or questions) only six respondents (10.5\%), which states often conducted this activity, thirty-six (63.2\%) reported occasionally, and fifteen respondents (26.3\%) reported never. Meanwhile twenty-nine respondents (50.9\%) reported often read the information in the group, not much different from the number of rarely done it (49.1\%).

Tabel 1 Students' Participation

\begin{tabular}{lcccccc}
\hline \multirow{2}{*}{ Question } & \multicolumn{2}{c}{ Often } & \multicolumn{2}{c}{ Occasionally } & \multicolumn{2}{c}{ Never } \\
\cline { 2 - 7 } & Respondent & $\%$ & Respondent & $\%$ & Respondent & $\%$ \\
\hline Post in FB Group & 6 & $10.5 \%$ & 36 & $63.2 \%$ & 15 & $26.3 \%$ \\
\hline $\begin{array}{l}\text { Checking information on } \\
\text { FB Group }\end{array}$ & 29 & $50.9 \%$ & 28 & $49.1 \%$ & 0 & $0 \%$ \\
\hline
\end{tabular}

Students' Interaction. We use a 5-point Likert scale (strongly agree to strongly disagree) but by eliminating the third point (undecided) because of the tendency of respondents to select this point. As presented in Table 2, FB group can be used to interact both with the lecturer and among students. 73\% said it helped to communicate with lecturer, $75.4 \%$ stated that getting feedback from lecturer, and $77.2 \%$ said it helped interact with classmates

Students Perspective on the Use FB Group for Education Purposes. The last questions on how the respondents' opinion about the use of FB group, the results showed that the majority agrees with the use of FB this group (see Table 2).

Table 2 The Use of FB group

\begin{tabular}{|c|c|c|c|c|c|c|c|c|}
\hline \multirow{2}{*}{ Question } & \multicolumn{2}{|c|}{ Strongly Agree } & \multicolumn{2}{|c|}{ Agree } & \multicolumn{2}{|c|}{ Disagree } & \multicolumn{2}{|l|}{$\begin{array}{l}\text { Strongly } \\
\text { Disagree }\end{array}$} \\
\hline & Respondent & $\%$ & Respondent & $\%$ & Respondent & $\%$ & Respondent & $\%$ \\
\hline $\begin{array}{l}\text { Provide proper information } \\
\text { about the lecture }\end{array}$ & 16 & $28.1 \%$ & 36 & $63.2 \%$ & 5 & $8.80 \%$ & - & - \\
\hline $\begin{array}{l}\text { As a media to interact with } \\
\text { friends }\end{array}$ & 8 & $14.0 \%$ & 44 & $77.2 \%$ & 5 & $8.8 \%$ & - & - \\
\hline $\begin{array}{l}\text { Helps me to communicate with } \\
\text { the lecturer }\end{array}$ & 13 & $22.8 \%$ & 42 & $73.7 \%$ & 2 & $3.5 \%$ & - & - \\
\hline $\begin{array}{l}\text { Helps us in getting feedbacks } \\
\text { from the lecturer }\end{array}$ & 10 & $17.5 \%$ & 43 & $75.4 \%$ & 4 & $7.0 \%$ & - & - \\
\hline A perfect media for studying & 14 & $24.6 \%$ & 38 & $66.7 \%$ & 5 & $8.8 \%$ & - & - \\
\hline
\end{tabular}


Applicable for the other

12

$21.1 \%$

37

$64.9 \%$

8

$14.0 \%$

Open-Ended Questions. Used to determine the benefits, difficulties, and suggestions related to the use of this group. Although as many as $73.7 \%$ (42 respondents) found it difficult when using FB group in the learning process (related to low internet connectivity), but nearly all respondents $(87.7 \%)$ found the group FB nice, interesting, and beneficial. Twenty respondents (35.1\%) suggested that the students do not use FB group to only upload assignment, but on a more active discussion and sharing of information related to the topic being discussed, "More discussion and updating information on the lecture" as stated by one of the respondents. Another added, "In the future, maybe we can make a chat group to discuss the subject that we don't understand, not just uploading assignments". The surprising result that three respondents said FB group should not be used in the learning process and it would be better if using other applications like WhatsApp messenger or BBM group.

\section{Discussion}

This study provides insight for educators on the use of social networks (FB group) in learning. Most students only read the information that exist in the FB group but did not do a post. This is because the assignment given is a group assignment, therefore only representatives of the group who did posted. They are who rarely read or check the info posted in the group, obtain information from classmates through other apps like BBM group and WhatsApp messenger. Members of this group should be more active for discussion and sharing of information related to the topic being discussed. Lecturer role is important in creating conditions that can encourage students to do so. Although the participation of students to engage in group still low, but most of them found FB group can help them interact with classmates and lecturer. Facebook has also been felt by students as a useful teaching aid.

\section{Limitation and Further Research}

This study was conducted on a small group of students in one course only and the results may not be generalized. Further research may involve students in several universities and levels of year to allow generalizations. Second, this study only uses FB group as a case study, further research can describe the impact of other social media in the students' learning process. Lastly, this study only uses the interaction dimension to see the impact on student engagement in FB group. Studies using other dimensions to discuss student engagement could be conducted in the future.

\section{References}

[1] Lifespan, "Texting, social networking and other media use linked to poor academic performance," $2013 . \quad$ [Online]. Available: www.sciencedaily.com/releases/2013/04/130411131755.htm. [Accessed: 01-Jul-2016].

[2] Kominfo, "Pengguna Internet di Indonesia 63 Juta Orang," 2013. [Online]. Available: 
https://kominfo.go.id/index.php/content/detail/3415/Kominfo+\%3A+Pengguna+Internet+di+In donesia+63+Juta+Orang///berita_satker. [Accessed: 01-Jul-2016].

[3] eMarketer, "Facebook Closes In on 1 Billion Mobile Users Worldwide," 2015. [Online]. Available: http://www.emarketer.com/Article/Facebook-Closes-on-1-Billion-Mobile-UsersWorldwide/1011881. [Accessed: 05-Jul-2016].

[4] J. M. Magogwe, B. Ntereke, and K. R. Phetlhe, "Facebook and classroom group work: A trial study involving University of Botswana Advanced Oral Presentation students," Br. J. Educ. Technol., vol. 45, no. 6, pp. 1312-1323, 2015.

[5] C. Madge, J. Meek, J. Wellens, and T. Hooley, "Facebook, social integration and informal learning at university: 'It is more for socialising and talking to friends about work than for actually doing work,"” Learn. Media Technol., vol. 34, no. 2, pp. 141-155, 2009.

[6] M. K. Kabilan, N. Ahmad, and M. J. Z. Abidin, "Internet and Higher Education Facebook: An online environment for learning of English in institutions of higher education?," Internet High. Educ., vol. 13, pp. 179-187, 2010.

[7] M. Mbodila, C. Ndebele, and K. Muhandji, “The Effect of Social Media on Student's Engagement and Collaboration in Higher Education: A Case Study of the Use of Facebook at a South African University," J. Commun., vol. 5, no. 2, pp. 115-125, 2014.

[8] H. Coates, Student Engagement in Campus-Based and Online Education: University Connections. New York: Routledge, 2006.

[9] G. D. Kuh, "Assessing What Really Matters to Student Learning Inside The National Survey of Student Engagement," Chang. Mag. High. Learn., vol. 33, no. 3, pp. 10-17, 2001.

[10] C. Windham, "The Student's Perspective," in Educating the Net Generation, D. G. Oblinger and J. L. Oblinger, Eds. Boulder, CO: EDUCAUSE, 2005, pp. 5.1-5.16.

[11] L. Taylor and J. Parsons, "Improving Student Engagement," Curr. Issues Educ., vol. 14, no. 1, 2011.

[12] J. D. Willms, "Student Engagement at School a Sense of Belonging and Participation," Paris, 2000.

[13] J. D. Willms, S. Friesen, and P. Milton, "What did you do in school today? Transforming classrooms through social, academic and intellectual engagement," Toronto: Canadian Education Association, 2009. 